\title{
THE INFLUENCE OF MAGNA CARTA LIBERTATUM IN THE DEVELOPMENT OF THE PRINCIPLE OF RULE OF LAW
}

DOI: $10.1515 /$ seeur-2015-0021

\begin{abstract}
The concept of Rule of Law is the cornerstone of the proper functioning of the judicial system in any modern democratic society. It is a basic concept of defined rights and liberties to all persons, which offers protection from arbitrary prosecution and incarceration. This principle was firstly stipulated by the instrument of Magna Carta and it is considered as a key principle for good governance in any modern democratic society. The development of the rule of law principle is personified through the independence of the Judiciary as a third branch of government. The contemporary democratic societies are faced with many challenges upon which in order to protect their values of the democratic system, often limit the rights and liberties of persons. It is the role of the courts and the judicial system to stop these injustices and protect the individual from any form of liberty deprivation and rights limitations. Before the promulgation of the Magna Carta in 1215, the rule of law was perceived as a divine justice, distributed solely by the monarch or the king or in this case - King John of England. Magna Carta doesn't have iconic status only in the British Society, which is perceived as an instrument with special constitutional status and cited by many judges, lawyers and politicians, but in any modern democratic states as well. The author in this article examines the development of the concept of Rule of Law in the modern democratic societies under the influence of the Magna Carta, and how it is perceived as a guarantee of fair trial and trial by jury of any persecuted persons whether the severity of their crimes.
\end{abstract}

\section{INTRODUCTION}

Before we explain the influence Magna Carta Libertatum has on the development of the rule of law, first we must explore what this document envisages, why is it so important to the development of the rule of law principle and does it really influence the modern legislation in terms of protection of fundamental rights and liberties of the persons. Magna Carta Libertatum or the Great Charter of Rights, is the first modern document which is described as the foundation of the freedom of the individual against the arbitrary authority of the despot. Basically this Charter envisaged protection of church rights, illegal imprisonment by the barons, access to swift justice and limitation of the feudal payments to the Crown. Magna Carta defines the principle of rule of law as protection of basic rights and liberties to all persons from arbitrary prosecution and incarceration. The few guarantees stipulated in this document represent the corner stone of the principle of Rule of Law in the modern world as well, because it envisages guarantees, such as trial by jury, access to swift justice, protection from arbitrary imprisonment and other civil liberties which are incorporated in the modern international documents 
for protection of human rights and civil liberties. Magna Carta still forms a symbol for liberty today. It is the most cited document by politicians and is held in great respect in the American and British legal communities. The rule of law principle stipulated in Magna Carta is the cornerstone of the modern judiciary as a third and independent branch of government and guarantees fair trial to all with maximum respect of their civil rights and liberties. However this article examines the consistency of several laws and acts, which are operating in the grey area of protection of human rights and procedural liberties, with the provisions stipulated in Magna Carta. The most controversial laws which at some point negate the provisions stipulated in Magna Carta are: The Military Commission Act od 2006 and The USA PATRIOT Act of 2004. These acts are perceived in the general and expert's public as acts which infringes even the most fundamental rights, such as the right to privacy, right to access to a lawyer, right to a fair trial, right to be judged by impartial court, right to legal aid and other civil liberties, which are protected by the international conventions and documents. The purpose of promulgation of such document, especially in the case of the Military Commissions Act and the USA PATRIOT act is to protect the democratic governance, but on what expense? The main question this article will answer is, what is the object for protection on these laws, and how are they compliant with the provisions of Magna Carta and other international documents, particularly in this case - the Geneva Conventions? Another issue this article is addressing is, on which expense is the protection of the democratic governance, is it on the expense on the procedural and human rights and liberties or something else?

\section{MILITARY COMMISSION ACT AND COMBATANT STATUS REVIEW TRIBUNAL}

The Military Commissions Act was promulgated in 2006 by the Congress of the United States, and it is also known as HR-6166 (Congress of the United States, Military Commissions Act of 2006). The primary purpose of this act was "to authorize trial by Military Commission for violations of the law of war and for other purposes". This act is an Act of Congress and it was drafted right after the US Supreme Court's decision on the case Hamdan vs Rumsfeld in 2006 (Opinion of the Supreme Court in Hamdan v. Rumsfeld (2006)). This decision of the US Supreme Court is of upmost importance because the court ruled the Combatant Status Review Tribunals set by the US Department of Defense as unconstitutional and procedurally flawed because they were not in compliance with the Geneva Conventions and did not provide sufficient protection of the detainees. These commissions prohibited the detainees who were classified as enemy combatants or were awaiting hearings on their status, from using "Habeas Corpus", which eventually all pending Habeas Corpus cases were stayed. However prior to the promulgation of the Military Commissions Act in 2006, the US Department of Defense in 2004 under the authorization of the President created special ad-hoc tribunals under the name of "Combatant Status Review Tribunals". It is not certain whether to use the term tribunal in this case, since this term refers to a court or panel of judges, which are obliged to adjudge in compliance with the international standards for fair trial and procedural justice. In this case these tribunals were create and administered by the executive branch of government.

\subsection{COMBATANT STATUS REVIEW TRIBUNALS}

The Combatant Status Review Tribunals were form of tribunals, established in 2004 by the US Department of Defense, to review the status of prisoners - detainees and to confirm whether the captured detainees had been correctly designated as enemy combatants (CRS Report for Congress Received through the CRS Web Detainees at Guantanamo Bay, 2005). These commissions were non public hearings and had an objective to conduct a formal review of all information related to a detainee in order to determine whether the detainee meets the criteria in order to be classified as an enemy combatant. However, the official definition for an enemy combatant varied over the years. The first definition described enemy combatants as "Persons who, either lawfully or unlawfully, directly engages in hostilities for an enemy state or non-state actor in an armed conflict". The 
current definition, according to the dictionary of the US Department of Defense, describes enemy combatants as "In general, a person engaged in hostilities against the United States or its coalition partners during an armed conflict"( United States, Depratment of Defense - Dictionary (2015)). In the United States the phrase enemy combatants was used after the attacks on 9/11 to include an alleged member of Al-Qaeda or Taliban being held in detention as part of the war on terror. The definitions of the lawful and unlawful enemy combatants are regulated with the Military Commissions Acts, and are examined thoroughly in the following chapter. The Combatant Status Review Commissions regarded the detainees as unlawful enemy combatants, which in other terms is a category of persons who do not qualify for a "Prisoner of War" status under the Geneva Conventions (Department of Defence, Guantanamo Detainee Processes 2, 2006). However if the detainees were found as a lawful enemy combatant they qualified for prisoner of war status under the Fourth Geneva Convention (Geneva Convention (IV) relative to the Protection of Civilian Persons in Time of War). The newly created definition of "enemy combatant" does not exclude the prisoner of war category and, as a result, its application by the tribunals cannot be used to justify denial of prisoner status. To take one clear example, the definition of "enemy combatant" includes any "individual who was part of or supporting Taliban or al Qaeda forces. This would include even the most obvious example of a prisoner of war defined in Article 4(A)(1) - Members of the armed forces of a Party to the conflict. Also the broad definition of "enemy combatant," including those "supporting Taliban or Al Qaeda forces. Though the administration has recognized that "the Geneva Convention applies to the Taliban detainees,", but on the other hand it has denied them prisoner status based on their membership in the Taliban, which qualifies them as enemy combatants. In fact, Department of Defense documents show that fully $50 \%$ of detainees appearing before the military commissions were alleged to be either Taliban or both al Qaeda and Taliban (Unclassified Summary of Basis for Tribunal Decision, 2006).

Most recently, the Obama Administration abandoned the use of the term enemy combatant, from the Bush administration (109th Congress 1st Session H. R. 1076, Detention of Enemy Combatants Act (Introduced in House)). The legal status of these tribunals was perceived as shady, operating within a grey area and non compliant with the provisions for protection of human rights and liberties stipulated in the international conventions and covenants of civil rights and other liberties. The tribunals were modeled after the procedures stipulated in the Army Regulations (AR 190-8 Tribunals). Under article 190-8 in the Army Regulations it is stated that the military creates such tribunals to determine the status of the defendants in compliance with Article 5 of the Third Geneva Convention. Article 5 states that "Should any doubt arise as to whether persons, having committed a belligerent act and having fallen into the hands of the enemy, belong to any of the categories enumerated in Article 4, such persons shall enjoy the protection of the present Convention until such time as their status has been determined by a competent tribunal"( Convention (III) relative to the Treatment of Prisoners of War, 1949). However this may have been the official explanation for the creation of these tribunals, the US Supreme Court in the case Hamdi vs. Rumsfeld stated that these tribunals were similar to the tribunals envisaged in Army Regulations AR-190-8 to make determinations on the factual status of the detainees. However the mandate of the current commissions and the tribunals differed in that AR-190 - Tribunals were only authorized to determine that captives were civilians, who should have been released, and in case when the detainees are classified as lawfully combatants, they should be protected from further prosecution under the Geneva Conventions.

The tribunals were not bound by the rules of evidence which apply to court. The tribunals only took in consideration the evidence or the "current available data" provided by the government under the presumption that that evidentiary material is genuine and accurate. Parties before the tribunals were the prosecutor, the detainee and his personal representative appointed by the government, which is not a lawyer, since the detainee has no right to petition for the Habeas Corpus, hence has no right to access to a lawyer. In the procedure before the tribunals, the government is required to present all the relevant evidentiary material, including the evidence that goes in favor of the detainee. The 
personal representative has an access to confidential material and may comment on it only to the tribunal in order to aid the status determination of the detainee. The tribunals were of a military nature and the identity of the presiding officers at these hearings is classified in order to guarantee anonymity. Also important role in the hearing plays the tribunal's recorder. The Tribunal's Recorder is tasked with keeping a record of the proceedings and present classified and unclassified material before the tribunals as well as explains or clarifies facts or unclear information. The attendance of the detainees in the procedure was not mandatory; however they had the right their personal statements to be read by their representative before the panel in their absence. Also the detainees had the right to translation and interpretation as well as the right a copy of the unclassified summary or information to be handed to them via their personal representative (Military Commissions Act of 2006). According to the information published on the web site of the US Department of Defense, it can be deducted that these proceedings were rudimentary, the detainees lacked proper legal representation and counsel and had no right to examine or cross examine witnesses ( Mariner, The Military Commissions Act of 2006: A Short Primer").

Turning point for declaring these tribunals unconstitutional was the case Boumediene v. Bush in 2008 in which the US Supreme Court found that Article 7 of the Military Commissions Act is unconstitutional because of its restriction to detainees rights (Opinion of Supreme Court in Boumediene v. Bush,US (2008)). The Supreme Court determined that the detainees had the right to petition before the federal courts for habeas corpus rights.

\subsection{PROVISIONS OF THE MILITARY COMMISSIONS ACT}

The Military Commissions Act contains several provisions which were declared unconstitutional by the Supreme Court. Such sections and articles from this act are:

- Section 948b - Military Commission Generally. This section in point (a) is establishing the procedures governing the use of military commissions to try unlawful enemy combatants engaged in hostilities against the US, for violations of the law of war and other offences under the jurisdiction of the military commission. Also this act authorizes the President to establish military commissions for offences triable under the jurisdiction of the military commissions. In point (c) of this section - Construction of the Provisions, are set forth the procedures for military commissions which are based upon the procedures for trial by general court martial under chapter 47 of the Uniform Code of Military Justice (Department of Defense, Uniform Code of Military Justice). However the difference here is that chapter 47 does not apply to the military commissions in terms of the rules of the investigative and main trial procedure. Point (d) regulates the inapplicability of certain provisions from the Uniform Code of Military Justice, which prohibit the detainee speedy trial, pre-trial investigation and self incrimination, which in other words, the government was responsible for collecting evidentiary material and presenting it before the tribunal. Point (e) envisages invalidation of the collected evidentiary materials, findings, interpretations or other precedents before military court - under the Uniform Code of Military Justice and civil courts. Points (f) and (g) of this act regulate the special status of the commissions, which this act recognizes them as a regular constituted court, and prohibition of the determined unlawful enemy combatants to invoke their rights under the Geneva Conventions. This entire section was founds unconstitutional by the Supreme Court, because envisages provisions which are infringing basic procedural rights and liberties of the detainees.

- Section 948d regulates the jurisdiction of the military commissions. This section is very important for the distinction of the lawful enemy combatants and unlawful enemy combatants, which are determined by the commission. In point (a) this section regulates the jurisdiction of the commission and clearly regulates that the commission has jurisdiction to try any criminal 
act punishable by the criminal code or the law of war committed before, on and after $9 / 11$. Point (b) and (c) envisage the definition of the lawful and unlawful enemy combatants and the jurisdiction of the military commissions under these categories. Under lawful enemy combatants, this act envisages: a) Person who is member of the regular forces of a State party engaged in hostilities against the United States; b) Member of the militia, volunteer corps, organized movement engaged in such hostilities which are under a command, wear distinctive uniform and carry arms openly. c) Member of the regular forces who professes allegiance to a government engaged in such hostilities. On the other hand unlawful enemy combatants this act considers: a) A person who has engaged in hostilities or who has purposefully and materially supported hostilities against the United States or its belligerents, who is not a lawful enemy combatant (including a person who is part of the Taliban, Al-Qaeda or associated forces; $b$ ) a person who, before, on or after the enactment of the Military Commissions Act of 2006, has been determined unlawful enemy combatant by a Combatant Status Review Tribunal or another competent tribunal established by the President or the Secretary of Defense. The jurisdiction of the commission varies between the lawful and the unlawful enemy combatants. Article (b) stipulates that the Military Commission shall not have jurisdiction over lawful enemy combatants. These type of combatants as subject under article 47 of the Uniform Code of Military Justice and enjoy protection under the Geneva Conventions. On the other hand the military commissions have absolute authority over the unlawful enemy combatants, who are found as such by the tribunals. The article further regulates that these combatants does not enjoy protection nor rights under the Geneva Conventions and have no right to access to court nor any other legal counsel. Point (d) regulates the penalties which the military commissions can adjudge. According to this, the commissions are allowed to adjudge any penalty unless prohibited by a clear order from the Secretary of State, including the death penalty.

Another notable provisions which are in conflict with the US Constitution and international documents and covenants of human, civil and political rights are:

- Section 949c, which envisages provisions which prohibit the use of a civilian defense attorney for the defense of the detainee, unless the attorney has been determined eligible for access to classified information (10 U.S.C. sec. 949c(b)(3)(D)).

- Section 949m, which envisages that in order for the detainee to be found guilty, a necessary $2 / 3$ majority is needed by the members of the commission present at the time of the voting (10 U.S.C. sec. $949 \mathrm{~m}(\mathrm{a}))$.

- Section 5(a), No person may invoke the Geneva Conventions or any protocols thereto in any habeas corpus or other civil action or proceeding to which the United States, or a current or former officer, employee, member of the Armed Forces, or other agent of the United States is a party as a source of rights in any court of the United States or its States or territories (Act sec. 5(a)).

These provisions were declared unconstitutional and annulled by the US Supreme Court in the case of Boumediene vs. Bush. From these provisions we can clearly see that they are opposite of the internationally accepted norms and standards for procedural rights of the persons deprived of liberty, stipulated even in the Magna Carta.

\section{USA PATRIOT ACT}

Another legislative example, which infringes guaranteed rights and liberties is the USA PATROT ACT. The whole name of this act is "Uniting and Strengthening America by Providing Appropriate Tools Required to Intercept and Obstruct Terrorism". It was promulgated by Congress and signed to law in October 2001. The main objective for passing this controversial act were the events on $9 / 11$ and the 
anthrax attacks which both occurred in 2001. This law was promulgated in order to strengthen security checks and controls on immigrants and US citizens as a precautionary measure in the fight against terrorism. This was the first law which was promulgated to increase the security on the cost of human rights, especially the right to privacy. This law was the cornerstone in the USA for the promulgation of other legislation such as the Military Commissions Act, which was examined above. The USA Patriot act made a number of amendments of other laws, such as: Foreign Intelligence Surveillance Act from 1978; Electronic Communications Privacy Act; Bank Secrecy Act and the Immigration and Nationality Act. This law has been followed with controversy since it allows for the NSA to collect cellular, internet and other data from all persons entering the USA, and from all US citizens. This law is criticized for its authorization of indefinite detentions of immigrants; the permission given law enforcement officers to search a home without the owner's or the occupant's consent or knowledge; conduction of illegal searches on telephone communications, e-mail, and other records without a court order. The unconstitutional element of the provisions is seen in the opportunity for governmental agencies to be able to intrude into person's privacy without an official court order, or a proper criminal investigation order.

Many provisions of the act were expected to end in the beginning of December 31, 2005. In the months preceding this date, supporters of the act pushed to make its sun-setting provisions permanent, while critics sought to revise various sections to enhance civil liberty protections. In July 2005, the U.S. Senate passed a reauthorization bill with substantial changes to several sections of the act (USA PATRIOT and Terrorism Prevention Reauthorization Act, 2005). The Patriot act was again extended in numerous occasions. The most notable extensions were the one in 2011, when the PATRIOT Sunset Extension Act was signed, which represent a four year extension on top three provisions of the Patriot act, which are: roving wiretaps, court-approved searches of records and property in anti-terrorism operations and conducting a surveillance on "Love Wolves" - non US individuals suspected of terrorist related activities. Later on on 1st of June 2015 several parts of the Patriot Act expired but were restored with the promulgation of the USA Freedom Act on 2nd of June (Democratic Underground, Obama signs Patriot). The Freedom act has brought several changes to some of the most critical provisions of the Patriot Act which enabled intrusion to privacy. This act imposes limits on the collection of bulk telecommunication data by the NSA on US citizens. This means that the phone companies can only share communication information when required by the NSA, only if there is a valid Federal Court Warrant (H.R.2048 - USA FREEDOM Act of 2015). The freedom act somehow fixes the damages committed by its predecessor in terms of limiting the intrusion of the Executive Branch into the privacy of both foreign and domestic persons and empowering the judiciary.

\section{CONCLUSION}

Magna Carta is the document with up most significance in the protection of the human rights and liberties. This document gave birth a noble idea which was incorporated in every important international document and national constitutions. They are placing the rule of law and the procedural rights and liberties of persons above everything else. They also guarantee fair trial with full due process of law, access to a defense counsel and right to information about the charges.

However since the attacks on 9/11, the whole concept of rule of law has changed dramatically. In order to protect the democratic governance, on the expense of the human rights and liberties, the Legislative bodies are producing laws, which tend to negate the very rights which are guaranteed by constitution and envisaged in every important international document and pacts. The newly introduced solutions, such as classification of lawful or unlawful enemy combatants which cannot invoke their rights stipulated in the Geneva Conventions are illegal, because it strips the persons or detainees of the very right to judicial protection which is the only institution who can distribute justice. 
The massive eavesdropping and collection of meta data by governmental agencies on persons without the existence of a legitimate court warrant also represents an infringement of personal liberties. Also it is very illegal and unconstitutional for the executive branch to replace the judiciary thorough authorization of creation and administration of ad-hoc tribunals, regardless of the cause. These two laws examined in this article has shown that regardless of the control of the executive branch of government, the only true protector of procedural rights and liberties and pillar of the rule of law principle is the judiciary as the third branch of government. The examples stated in this text shows that strong judiciary is necessary in order to oppose the promulgation of illegitimate laws. Through its opinions and judgments, the judiciary represents a true safeguard of the principle of rule of law and procedural right of all persons deprived of liberty.

\section{WORKS CITED}

H.R.2048 - USA FREEDOM Act of 2015, https://www.congress.gov/bill/114th-congress/housebill/2048/text

Democratic Underground - Obama signs Patriot Act

http://www.democraticunderground.com/discuss/duboard.php?az=view_all\&address=102x4287047

USA PATRIOT and Terrorism Prevention Reauthorization Act of 2005 (U.S. H.R. 3199, Public Law 100-117),

Mariner, Joanne (October 9, 2006). "The Military Commissions Act of 2006: A Short Primer", http://writ.news.findlaw.com/mariner/20061009.html

Opinion of Supreme Court in Boumediene v. Bush, US (2008), http://www.supremecourt.gov/opinions/07pdf/06-1195.pdf

Opinion of the Supreme Court in Hamdan v.

Rumsfeld,http://www.supremecourt.gov/opinions/05pdf/05-184.pdf

CRS Report for Congress Received through the CRS Web Detainees at Guantanamo Bay (2005) Jennifer K. Elsea Legislative Attorney American Law Division,

http://www.fas.org/sgp/crs/natsec/RS22173.pdf

Detention of Enemy Combatants Act (Introduced in House) 109th CONGRESS 1st Session H. R. 1076 March 3, 2005, http://thomas.loc.gov/cgi-bin/query/z?c109:H.R.1076.IH:

United States, Depratment of Defense - Dictionary (2015)

http://www.dtic.mil/doctrine/new_pubs/jp1_02.pdf

AR 190-8 Enemy Prisoners of War, Retained Personnel, Civilian Internees and Other Detainees, http://ssitoday.armylive.dodlive.mil/ar-190-8-enemy-prisoners-of-war-retained-personnel-civilianinternees-and-other-detainees/

Convention (III) relative to the Treatment of Prisoners of War. Geneva, 12 August 1949, https://www.icrc.org/applic/ihl/ihl.nsf/7c4d08d9b287a42141256739003e636b/6fef854a3517b75ac125 $641 \mathrm{e} 004 \mathrm{a} 9 \mathrm{e} 68$

Geneva Convention (IV) relative to the Protection of Civilian Persons in Time of War. Geneva, 12 August 1949, https://www.icrc.org/ihl/INTRO/380

Department of Defence, Guantanamo Detainee Processes 2 (June 9, 2006), http://www.defenselink. mil/news/Sep2005/d20050908process.pdf 
Department of Justice, United Code of Military Justice, 64 Stat. 109, 10 U.S.C. $\S \S 801-946$, https://www.law.cornell.edu/uscode/text/10/subtitle-A/part-II/chapter-47

Unclassified Summary of Basis for Tribunal Decision, at NOV00091, http://www.dod.mil/pubs/foi/detainees/CSRT_JTF_GTMO_documents.pdf 